\title{
Acoustic Voice Analysis Findings in Ankylosing Spondylitis
}

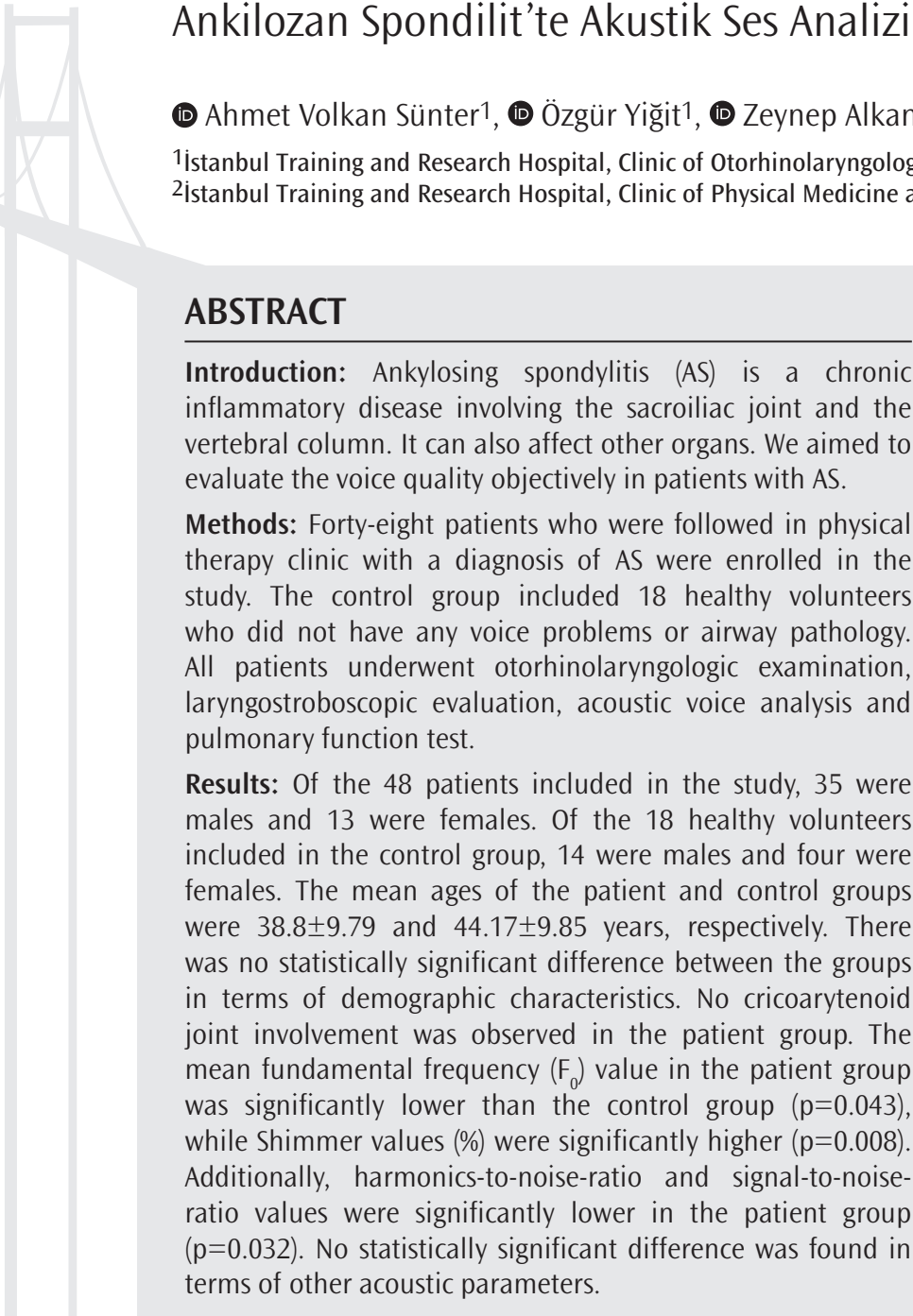

Conclusion: In our study, $\mathrm{F}_{0}$ in patients with AS was lower than the control group. This may be related to reduced respiratory capacity of patients with AS.

Keywords: Acoustic voice analysis, ankylosing spondylitis, fundamental frequency

\section{öZ}

Amaç: Ankilozan spondilit (AS) özellikle sakroiliak eklem ve vertebral kolonu tutan kronik enflamatuvar bir hastalıktır. Bunun yanında diğer organları da etkileyebilmektedir. Bu çalışmada AS'li hastalarda ses kalitesini objektif olarak değerlendirmeyi amaçladık.

Yöntemler: AS tanısı nedeniyle fizik tedavi bölümünde takip edilen 48 hasta çalışmaya dahil edildi. Kontrol grubu olarak ise herhangi bir ses problemi veya solunum yolu patolojisi bulunmayan 18 sağlıklı gönüllü çalışmaya dahil edildi. Tüm hastalara genel kulak burun boğaz muayenesi, laringostroboskopik değerlendirme, akustik ses analizi ve solunum fonksiyon testleri yapıldı.

Bulgular: Çalıșmaya dahil edilen 48 hastanın 35 ’i erkek, 13'ü kadın olup kontrol grubuna dahil edilen 18 sağlıklı gönüllünün ise 14 'ü erkek, 4'ü kadındı. Hasta grubunun yaş ortalaması 38,8 $\pm 9,79$ olarak bulunurken kontrol grubunun

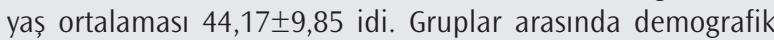
özellikler açısından anlamlı bir farklılık gözlenmemiștir. Çalıșma hastalarının hiçbirinde krikoaritenoid eklem tutulumu saptanmamıștır. Çalıșma grubunda kontrol grubuna göre ortalama temel frekans $\left(F_{0}\right)$ değerleri istatistiksel olarak anlamlı oranda daha düşük $(p=0,043)$ bulunurken, Shimmer değerleri (\%) anlamlı oranda daha yüksek $(p=0,008)$ bulunmuştur. Harmonik-gürültü oranı (HNR) ve sinyal-gürültü oranı (SNR) değerleri ise yine çalışma grubunda istatistiksel olarak anlamlı oranda daha düşüktü $(p=0,032)$. Diğer akustik parametrelerde istatistiksel olarak anlamlı bir değișiklik saptanmadı.

Sonuç: Çalışmamızda AS'li hastalarda sesin temel frekansı kontrol grubuna göre daha düșük bulunmuștur. Bu durum AS'li hastaların azalmış respiratuvar kapasiteleri ile ilgili olabilir.

Anahtar Kelimeler: Akustik ses analizi, ankilozan spondilit, temel frekans
Address for Correspondence/Yazıșma Adresi: Ahmet Volkan Sünter MD, İstanbul Training and Research Hospital, Clinic of Otorhinolaryngology, İstanbul, Turkey

Phone: +90 2124596440 E-mail: avsunter@gmail.com ORCID ID: orcid.org/0000-0001-8601-0450

Cite this article as/Atıf: Sünter AV, Yiğit Ö, Alkan Z, Burnaz Ö. Acoustic Voice Analysis Findings in Ankylosing Spondylitis. İstanbul Med J 2019; 20(3): 231-3.
Received/Geliș Tarihi: 13.10.2018 Accepted/Kabul Tarihi: 22.11.2018

(c) Copyright 2019 by the Istanbul Training and Research Hospital/istanbul Medical Journal published by Galenos Publishing House.

(C) Telif Hakkı 2019 İstanbul Ĕgitim ve Araștırma Hastanesi/Istanbul Tıp Dergisi, Galenos Yayınevi tarafından basılmıștır. 


\section{Introduction}

Ankylosing spondylitis (AS) is a chronic inflammatory disease that involves the sacroiliac joint and the vertebral column. It can involve other joints as well, but rarely can involve extra-articular soft tissues. In addition to joint problems, atypical manifestations such as uveitis, cardiac conduction disorders, pulmonary fibrosis and renal amyloidosis may be observed in patients. In addition to the most frequently involved sacroiliac joint, the joints of the larynx can be involved and the cricoarytenoid joint involvement is the most common. Hoarseness due to vocal cord paralysis may be the first symptom in patients. When lung involvement is present in these patients, lung capacity decreases and shortness of breath develops (1). As it is known, hoarseness may be due to laryngeal pathologies and extra-laryngeal pathologies may also affect voice quality. Decreased lung capacity may impair the quality of voice due to inability to breathe during phonation.

In our study, we aimed to investigate the changes in voice quality due to decreased lung capacity in patients with pulmonary involvement but without cricoarytenoid joint involvement by voice analysis.

\section{Methods}

Local Ethics Committee of İstanbul Training and Research Hospital approved this study (decision no: 2009-25). The patient group consisted of 48 AS patients who were followed up at the İstanbul Training and Research Hospital Physical Therapy and Rehabilitation Clinic without lung involvement. The control group consisted of 40 people without hoarseness and lung problems. All patients and voluntary individuals included in the study were explained in detail and written informed consent was obtained. Laryngeal examinations of the patient and control groups were performed by videolaryngostroboscopy (Karl Storz, Pulsar Model 20140020, Tuttlingen, Germany). Following exclusion of patients with vocal cord lesions that can cause hoarseness, vocal cord paralysis, history of laryngeal surgery, smoking and inhaler use, voice quality and function were analyzed using acoustic voice analysis (Dr. Speech, Version 4, Tiger DRS, USA). Pulmonary function test was performed, and patients with FEV1 less than 80 were considered to have pulmonary involvement and these patients were excluded from the study. Voice analysis was performed at least 3 times and the best performance was taken into consideration for analysis. Acoustic analysis parameters of all patients were evaluated statistically.

\section{Statistical Analysis}

Statistical analysis was performed with NCSS 2007 (NCSS, LLC, Utah, USA) package program. In addition to descriptive statistical methods (mean \pm standard deviation), independent t-test was used for pairwise comparison of groups, $x^{2}$ test was used for comparison of qualitative data and Pearson correlation test was used to determine the relationship between variables. The results were evaluated at $p<0.05$ level.

\section{Results}

Thirty-five patients were male and 13 were female and their ages ranged from $16-60$ years (mean age: $38.8 \pm 9.79$ years). The control group consisted of 30 male and 10 female, and their ages ranged from 17 to 58 years (mean age: $37.3 \pm 8.65$ years). The mean duration of disease
Table 1. Voice analysis findings of the study and control groups

\begin{tabular}{|l|l|l|l|l|}
\hline & $\begin{array}{l}\text { Patient group, } \\
\mathbf{n}=\mathbf{4 8}\end{array}$ & $\begin{array}{l}\text { Control group, } \\
\mathbf{n}=\mathbf{3 0}\end{array}$ & $\mathbf{t}$ & $\mathbf{p}$ \\
\hline $\mathbf{F}_{\mathbf{0}} \mathbf{( H z )}$ & $157.37 \pm 43.63$ & $183.14 \pm 49.46$ & -2.06 & 0.043 \\
\hline Jitter (\%) & $0.24 \pm 0.13$ & $0.21 \pm 0.07$ & 0.84 & 0.404 \\
\hline Shimmer (\%) & $2.72 \pm 1.24$ & $1.88 \pm 0.63$ & 2.72 & 0.008 \\
\hline HNR & $20.08 \pm 2.4$ & $21.6 \pm 2.81$ & -2.19 & 0.032 \\
\hline SNR & $18.69 \pm 2.45$ & $20.24 \pm 2.85$ & -2.20 & 0.032 \\
\hline MPT & $12.89 \pm 6.38$ & $12.86 \pm 5.91$ & 0.02 & 0.985 \\
\hline s/z rate & $0.18 \pm 0.25$ & $0.26 \pm 0.3$ & -1.16 & 0.250 \\
\hline
\end{tabular}

$F_{0}$ : fundamental frequency, HNR: harmonics to noise ratio, SNR: signal to noise ratio, MPT: maximum phonation time

was 4 years ( 2 months-37 years). Mean $\mathrm{F}_{0}$ values were significantly lower in the patient group compared to the control group ( $p=0.043)$, whereas Shimmer values were significantly higher than the control group $(p=0.008)$. Harmonics-to-noise-ratio and signal-to-noise-ratio (SNR) were statistically significantly lower in the patient group $(p=0.032$ ). There was no statistically significant difference between the mean maximum phonation time of the patient and control groups $(p=0.985)$. There was no statistically significant difference between the $s / z$ rates of the patient and control groups $(p=0.250)$. There was no statistically significant difference between the Jitter (\%) means of the patient and control groups $(p=0.440)$ (Table 1). In addition, there was a significant difference in Shimmer and $\mathrm{F}_{0}$ values with decreased respiratory capacity in respiratory function tests.

\section{Discussion}

There are various symptoms in AS depending on affected joint and these symptoms often involve multiple medical departments. Otologic involvement has been identified in the department of ear, nose and throat, and many studies and cases have been presented. Magaro et al. (2) reported conductive hearing loss due to otologic involvement, while other studies reported sensorineural hearing loss due to internal ear involvement (3-5).

Restriction of neck extension in cervical vertebrae due to AS leads to difficult intubation. The fact that the joints in the laryngeal structures are target points often cause vocal and swallowing difficulties in patients. The involvement of the cricoarytenoid joint is observed in rheumatic diseases, especially in rheumatoid arthritis, which is close to $25 \%$ (6). In addition, it can be observed rarely in AS patients $(7,8)$. Although this involvement is usually bilateral, it may be in the form of unilateral joint involvement. In these patients, hoarseness and shortness of breath are the most common findings with the limitation of vocal cord movements. One study reported that cricoarytenoid joint involvement responded well to steroid therapy but had a tendency to recur after discontinuation of treatment (7-8).

Cricoarytenoid joint involvement may not always be accompanied by limitation of vocal cord movements. The rate of cricoarytenoid joint involvement increases with increasing duration of the disease. Even in one case, vocal cord fixation has emerged as the first symptom of the disease (9). Laryngeal electromyography may be useful in the differential 
diagnosis of vocal cord paralysis in cases where vocal cord mobility is decreased and cricoarytenoid joint involvement is suspected.

Pulmonary involvement is also very common in AS patients, and restrictive type of respiratory problems develop due to reduced movement of the chest wall. Pulmonary function tests often show a marked decline in forced vital capacity. This is associated with decreased thoracic expansibility $(1,10)$. Reduction of lung capacity is a common finding in patients with AS, even if it does not clinically cause symptoms. In these patients, severe respiratory problems occur as the duration of disease progresses.

The most important elements in the formation of voice are the expiratory air from the lungs, the vibratory vocal cords and the vocal tract that acts as resonator. It is known that the voice becomes weak due to decreased lung capacity. In patients with AS, decreased lung capacity, decreased vocal cord mobility, and decreased vocal tract volume may prevent the formation of a healthy voice. All these conditions may be closely related to the duration of the disease, but the degree of involvement in the joint is more important. When compared to the control group in our study, it was seen that the mean frequency of voice was significantly decreased and the shimmer values were significantly increased in the AS group. These changes were thought to be due to restrictive lung disease. Positive correlation between increased restrictive respiratory distress in the pulmonary function test and impairment in these values also support this.

However, in these patients, hoarseness may be confounded not only by joint restriction, but also due to involvement in other regions affecting the quality of the voice. Eliminating the problems in these regions as much as possible in the treatment will solve or reduce these accompanying problems.

\section{Conclusion}

In our study, the $\mathrm{F}_{0}$ in AS patients was lower than the control group. This may be related to reduced respiratory capacity of AS patients.

Ethics Committee Approval: Local Ethics Committee of İstanbul Training and Research Hospital approved this study (decision no: 2009-25).
Informed Consent: All patients and voluntary individuals included in the study were explained in detail and written informed consent was obtained

Peer-review: Externally peer-reviewed.

Author Contributions: Concept - A.V.S., Z.A.; Design - A.V.S., Ö.Y., Z.A., Ö.B.; Supervision - A.V.S., Ö.Y.; Resources - A.V.S., Ö.Y., Z.A., Ö.B.; Materials - A.V.S., Ö.Y., Z.A., Ö.B.; Data Collection and/or Processing A.V.S., Ö.Y., Z.A., Ö.B.; Analysis and/or Interpretation - A.V.S., Ö.Y., Z.A., Ö.B.; Literature Search - A.V.S.; Writing Manuscript - A.V.S., Ö.Y.; Critical Review - A.V.S., Ö.Y.

Conflict of Interest: No conflict of interest was declared by the authors.

Financial Disclosure: The authors declared that this study received no financial support.

\section{References}

1. Sampaio-Barros PD, Cerqueira EM, Rezende SM, Maeda L, Conde RA, Zanardi VA, et al. Pulmonary involvement in ankylosing spondylitis. Clin Rheumatol 2007; 26: 225-30.

2. Magaro M, Ceresia G, Frustaci A. Arthritis of the middle ear in ankylosing spondylitis. Ann Rheum Dis 1984; 43: 658-9.

3. Alatas N, Yazgan P, Oztürk A, San I, Iynen I. Audiological findings in patients with ankylosing spondylitis. J Laryngol Otol 2005; 119: 534-9.

4. Casellini C, Citera G, Rosemffet M, Ruggeri S, Saviotti A, Maldonado Cocco JA. Audiovestibular disorders in patients with ankylosing spondylitis. J Clin Rheumatol 2005; 11: 81-5

5. De Miguel E, Tomas M, Benito S, Gavilan J, Gijon J. Ankylosing spondylitis and middle ear impairment. Ann Rheum Dis 1987; 46:174.

6. Beirith SC, Ikino CM, Pereira IA. Laryngeal involvement in rheumatoid arthritis. Braz J Otorhinolaryngol 2013; 79: 233-8.

7. Wojtulewski JA, Sturrock RD, Branfoot AC, Hart FD. Cricoarytenoid arthritis in ankylosing spondylitis Br Med J 1973; 3: 145-6.

8. Bienenstock H, Lanyi VF. Cricoarytenoid arthritis in a patient with ankylosing spondylitis. Arch Otolaryngol 1977; 103: 738-9.

9. Miller FR, Wanamaker JR, Hicks DM, Tucker HM. Cricoarytenoid arthritis and ankylosing spondylitis. Arch Otolaryngol Head Neck Surg 1994; 120: 214-6.

10. Feltelius N, Hedenstrom H, Hillerdal G, Hallgren R. Pulmonary involvement in ankylosing spondylitis. Ann Rheum Dis 1986; 45: 736-40. 